\title{
ディーゼル噴霧火炎内のすす生成に関する化学反応論的解析*
}

\author{
伊 藤 貴 之*1, 保 坂 智 史*2 \\ 千 田二 郎*3, 藤 本 元*3
}

\section{Detailed Kinetic Analysis for Soot Formation in a Diesel Jet Flame}

\author{
Takayuki ITO, Tomofumi HOSAKA, \\ Jiro SENDA*4 and Hajime FUJIMOTO \\ ${ }^{* 4}$ Department of Mechanical Engineering, Doshisha University, \\ 1-3 Miyakodani, Tatara, Kyotanabe-shi, Kyoto, 610-0321 Japan
}

\begin{abstract}
This work investigates the soot formation process in a diesel jet flame using a detailed kinetic soot model implemented into the KIVA-3 V multidimensional CFD code. The numerical model is based on the KIVA code which is modified to use CHEMKIN as the chemistry solver. The detailed soot model used is based on the method of moments, which begins with fuel pyrolysis, followed by the formation of polycyclic aromatic hydrocarbons, their growth and coagulation into spherical particles, and finally, surface growth and oxidation of the particles. The model can describe the spatial and temporal characteristics of soot formation processes such as soot precursors distributions, nucleation rate and surface reaction rate. The calculation results show that the soot particles are formed to surround the soot precursor formation region and to extend downstream. It is also found that the dominant soot growth process differs by the region in the fuel jet. The particle inception is fast around the central region of the jet, and $\mathrm{C}_{2} \mathrm{H}_{2}$ surface reaction rate becomes higher toward the periphery of the jet.
\end{abstract}

Key Words: Diesel Engine, Combustion, Chemical Kinetics, Soot Formation, Computational Fluid Dynamics

\section{1. 精㣜}

ディーゼルエンジンは熱効率が高く, 地球温暖化 の原因となる $\mathrm{CO}_{2}$ 排出量の点で他の熱機関を圧倒する にもかかわらず，微粒子状物質および窒素酸化物の排 出など，解決すべき問題が多く残されている. 特に, ディーゼル噴霧然焼場における微粒子状物質の生成は 物理的過程と化学的過程が絡み合う複雑な現象であり, その生成・成長過程は十分に解明されたとは言い難い. しかしながら, エンジンからの微粒子排出低减には筒 内での燃焼状態と微粒子生成過程の相関を詳細に調べ ることが不可欠であり，これまでに多くの実験および 数値解析が行われている.

近年のレーザ計測技術の発展により，ディーゼル 噴霧燃焼場におけるす寸生成過程の詳細が明らかにさ れつつある. 小酒ら (1)はレーザ誘起赤熱法 (UII) およ びレーザ誘起散乱光法（US）を自由噴霧火炎に適用 し，自由噴霧火炎断面内の相対すす濃度，相対す寸粒

\footnotetext{
* 原稿受付 2004 年 2 月 5 日.

*1 正員, 同志社大学大学院工学研究科(- 610-0321 京田辺市 多々羅都谷 1-3).

*2 学生員, 同志社大学大学院工学研究科.

*3 正員, 同志社大学工学部.

E-mail : jsenda@mail.doshisha.ac.jp
}

径, 相対す寸数密度の 2 次元分布を測定している. そ の結果，噴霧火炎中心領域ではすすの生成が開始され る領域であるため，小粒径・高数密度のすすが確認さ れ，火炎先端周囲領域では凝集・合体により，大粒 径・低数密度のす寸に成長していることが明らかとな った. 更に，相澤らさは僅かな時間差を設けた紫外光 および赤外光レーザにより，すす前駆体である多環芳 香族 (PAH) のレーザ誘起蛍光法 (LF) と LII の同時 2 次元計測を行い，すす粒子からの UII シグナルは PAHからの LF シグナルが観測される領域の周囲に分 布し，下流方向一広がって行くことを明らかにしてい る.

一方，ディーゼル然焼シミュレーションにおける す寸生成予測は現象論モデルによるものが殆どである B) (4). 現象論モデルでは，核生成や凝集，表面反応な どのす寸生成の諸過程を詳細に追跡することは困難で ある.これに対し，混合気組成，温度が均一な場にお いては，詳細な化学反忘過程を考慮したす寸生成特性 の解析が可能になりつつある(の). そこで本研究では, これらの化学反応過程を考慮した詳細す寸生成モデル を多次元 CFD に組み込み，ディーゼル噴霧火炎内に おけるすす生成過程の解析を行った. 


\section{2. 計算手法およびモデル}

本研究では, 草鹿らのと同様に多次元流体解析コ一 ド KIVA-3V(8)に反忘解析コード CHEMKINのの一部を直 接組み込むことで, 詳細反応を考慮した多次元シミュ レーションを可能とした，両コードの結合は KIVAに おける各計算タイムステップにおいて, 各計算格子内 の化学種濃度, 温度, 圧力などの熱力学情報を CHEMKIN へ受け渡し, CHEMKIN で計算された化学 種濃度変化量を KIVAへ返すことで実現される.

\section{1 燃佬モデル}

計算格子内において, 燃料蒸気, 酸化剂および燃 焼生成物は分子レベルで均一に混合しているとは限ら ず，化学反応速度と乱流混合速度の関係を記述する燃 焼モデルが必要とされる. 本研究では Kong らのモデ ル(10を一部修正して使用した. 以下にその概略を述べ る.

本モデルでは, 反応速度は乱流特性時間と反応特 性時間から決定される. 各化学種の反応特性時間は完 全均一条件下において, 化学種濃度が平衡状態に達す るまでに必要とされる時間であり, 乱流特性時間は渦 塊の崩壊に要する時間として決定される.ここで乱流 特性時間は全化学種に対して同一に与えられるが, 反 応特性時間は各化学種によって異なり, 化学種 $i$ の生 成速度は次式で表される.

$$
\omega_{i}=\frac{Y_{i}^{*}-Y_{i}}{\tau_{k i n, i}+f \tau_{t u r b}}
$$

ここで， $Y_{i}$ は化学種濃度， $Y_{i}^{*}$ は瞬時局所平衡濃度， $\tau_{i j i}$ は反応特性時間, $\tau_{n b}$ は乱流特性時間であり, 乱れ工 ネルギ $k$ と消散率をを用いて, $k d$ に比例する形で表さ れる. また, $f$ は燃焼の進行度によって $0 \sim 1$ まで変化 する值であり，Kong ら (11)に従って与えた. ここで完全 な化学反応律速の場合, 乱流特性時間が無視でき, 式 (1)は次式のように表される.

$$
\omega_{k i n, i}=\frac{Y_{i}^{*}-Y_{i}}{\tau_{k i n, i}}
$$

また, 反応律速での化学種の生成速度は CHEMKIN による解を用いると, 次式でも表される.

$$
\omega_{k i n, i}=\frac{Y_{i}^{\prime}-Y_{i}}{d t}=\frac{\Delta Y_{i}}{d t}
$$

ここで，dは KIVAの時間刻み， $Y_{i} ， Y_{i}^{\prime}$ はそれぞれ， CHEMKIN 計算ルーチンの実行前後での化学種濃度で
ある. 式(2)，(3)より，各化学種の反応特性時間と平衡 濃度の関係は次式となる.

$$
\tau_{k i n, i}=\frac{Y_{i}^{*}-Y_{i}}{\Delta Y_{i}} d t
$$

ここで, タイムステップ毎に各化学種の瞬時局所平衡 濃度を求め, それぞれの反応特性時間を決定すると,

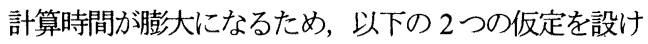
る.

(1) すべての化学種の反応特性時間は燃料種のもの と等しい.

（2）燃料はたとえ燃料過濃条件下においても，反応 開始直後に熱分解反応等により, 中間生成物一 と変化してゆくため, 燃料化学種の瞬時局所平 衡濃度はゼロである.

この仮定により,すべての化学種の反応特性時間お よひ瞬時局所平衡濃度は CHEMKIN の結果を利用して 以下で表される.

$$
\begin{aligned}
& \tau_{k i n}=\left(-Y_{f} / \Delta Y_{f}\right) d t \\
& Y_{i}^{*}-Y_{i}=\left(-Y_{f} / \Delta Y_{f}\right) \Delta Y_{i} \\
& Y_{i}^{*}-Y_{i}=\tau_{k i n} \Delta Y_{f} / d t
\end{aligned}
$$

ここで， $\Delta Y_{f} \Delta Y_{i}$ は CHEMKIN の計算結果から得ら れた燃料種および化学種 $i$ の濃度変化量である. ただ し, 燃料種の濃度がゼロの場合は，反応特性時間が極 めて小さく見積もられるため，燃料過濃および希薄条 件でそれぞれ平衡濃度がゼロに向かう $\mathrm{O}_{2}$ および 00 の反応特性時間の大きい方で代替した.

式(1), (7)から, 各タイムステップにおける化学種 濃度変化量は次式で得られる.

$$
Y_{i}^{n+1}-Y_{i}^{n}=\frac{\tau_{k i n}}{\tau_{k i n}+f \tau_{\text {turb }}} \Delta Y_{i}
$$

\section{2 詳細すす生成䵢力学モデル}

本研究で使用したすす反応動力学モデルは, これ までに均一混合気を対象に行なったすす生成特性解析 ので用いたものとほぼ同様であり，図 1 に示すように, 燃料の酸化・熱分解から四環までの PAH 生成を記述 できる気相反応モデルと, PAH からの粒子核生成, 粒子同士の凝集, PAH の粒子表面への凝縮, および 気相化学種による表面成長・酸化反応を記述するす寸 粒子生成モデルから構成される．以下にその概略を示 す。 
気相反応モデルは，燃料の酸化・熱分解反応，お よび多環化反応に大別される．酸化・熱分解反応モデ ルには Curranのnープタン酸化反応モデル(1)を基に簡 略化された Golovichev らのモデル(13)を使用した。この モデルはディーゼル噴霧の着火過程を再現する上で重 要となる低温酸化反応機構を含み, 均一予混合気の着 火遅れの温度，圧力依存性を良く再現できる。

また，多環化反応モデルには，芳香族環への水素 引き拔き-アセチレン付加反応（HACA sequenœ），芳 香族環同士の結合反応，およびアロマラジカルへのビ ニルアセチレン付加を考慮している Apple らのモデル (14)を用いた。 このモデルは多くの一次元平面予混合火 炎内の多環芳香族濃度分布を良く再現できることが確 かめられている.これに上記の nヘプタン酸化反応モ デルを組み合わせることで, 最終的に気相反応モデル は化学種総数 118 , 反応式総数 606 て構成される.

一方，す寸粒子生成モデルには Frenklach らのモ一 メント法による粒子生成モデル(1)を使用した。 モーメ ント法は，粒子に対して次式の濃度モ一メントを定義 することで，無限個の微分方程式の解法を回避できる 利点老持つ。

$$
M_{r}=\sum_{i=1}^{\infty} m_{i}^{r} N_{i}
$$

ここで, $M_{r}$ は粒子の $r$ 次濃度モーメント $m_{i}$ : サイ ズクラス $i$ の粒子中の炭素原子数, $N_{i}$ : サイズクラス $i$ の粒子数密度を示寸. 気相反応計算により算出される 温度および気相化学種濃度 (四環芳香族, アセチレン, 水素分子, 水素原子, 酸素分子, $\mathrm{OH}$ ラジカル) を入 カデータとし，す寸粒子の生成・成長を記述するモ一 メント方程式を解くことで，す寸体積濃度およひ粒子 数密度などの統計的物理量を求めることができる. な

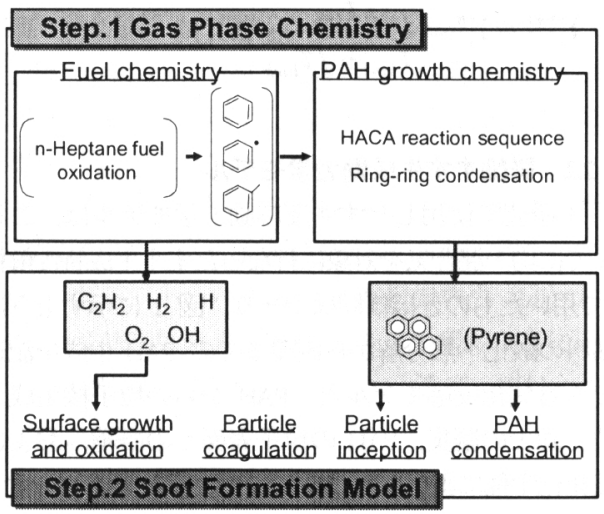

Fig. 1 Schematic diagram of soot formation model
お，モーメント法については文献15]に詳しい。

\section{3 計算手法}

本研究のように, KIVAの各タイムステップ, 計算 格子において CHEMKINによるサブサイクルを計算す る場合, 大規模な反応モデルの導入や計算格子の細分 化が，膨大な計算時間を招いてしまう。 そこで本研究 では，図2に示寸ように, MPI(Message-Passing Interface)に より, 最も計算時間を要する化学反応計算ルーチンを 計算格子に対して並列化することで，計算時間の短縮 を図った，並列化による計算速度の向上は次式により 予測可能である.

$$
S=\frac{1}{(1-F)+\frac{F}{N}}
$$

ここで， $S$ は計算速度の向上倍率， $F$ は計算時間全体 における並列化割合, $N$ は計算ノ一ト数（計算を担当 する CPU の数) を表す，本計算では計算に要する時 間の $95 \%$ 以上が反応計算に費やされるため, 反応計算 ルーチン(CHEMKIN)を計算格子に対して並列化するこ とで大幅な速度向上が望める。計算には Pentium4 $2.53 \mathrm{GHz}$ ，メモリ $512 \mathrm{MB}$ のPC8台を 100Mbit Ethemet で接 続した Linux クラスタを使用した。

\section{3. その他のサブモデルおよび計算条件}

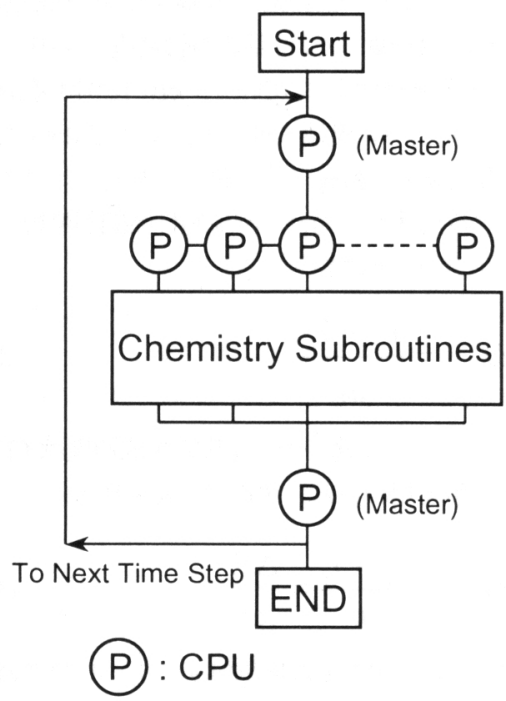

Fig. 2 Flow chart of calculation with multiple CPUs 
燃料液滴の分裂モデルには修正 TAB モデルは1も, 乱流モデルには RNGk-Eモデル(17を用いた.

軽油は膨大な種類の炭化水素から構成される多成分 燃料であるため, 未だ軽油を対象とした素反応モデル は構築されていない，そこで，燃料は軽油と同等のセ タン価を有するnヘプタンとし，表１亿示寸条件下で 計算を行った，なお計算は簡単のため, 半径 $30 \mathrm{~mm}$, 噴射軸方向 $120 \mathrm{~mm}$ の円筒空間とし，それぞれ $60 \times 80$ 分割した 2 次元メッシュを用いて行なった.

この条件て燃料噴射開始後 $10 \mathrm{~ms}$ までの計算に上記 PCクラスタを用いて約 40時間を要した.

Table 1 Calculation condition

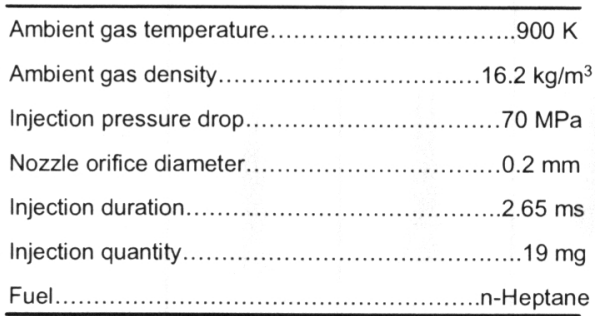

\section{4. 計算結果}

4.1 熱発生率に関する実験結果との比較

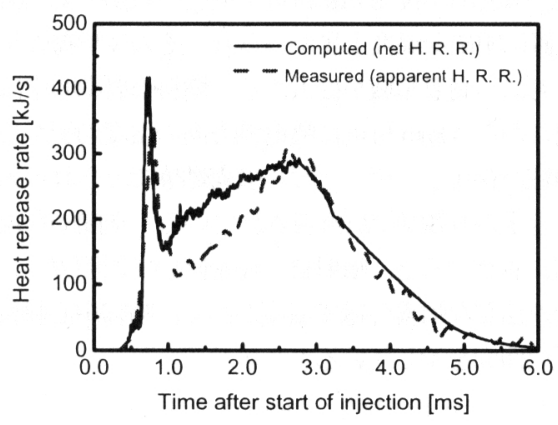

Fig. 3 Comparison of calculated and measured heat release rate

図 3 に計算により得られた熱発生率線図を示す。 図には同一条件下において定容燃焼容器を用いて行わ れた実験のものも併記してある，着火遅れ期間は実験 とかなり良い一致を示している，また，着火直後に見 られる予混合的燃焼によるスパイク状の熱発生率形状 および拡散然焼期の熱発生率も実験をよく再現できて いると思われる.

\section{2 噴霧火炎発達過程}

燃料噴霧の燃焼による温度分布の時間変化を図 4 に示寸。ここで，TASI は燃料噴射開始からの時間を 表す。また，図中のドットは液滴の存在領域を示して

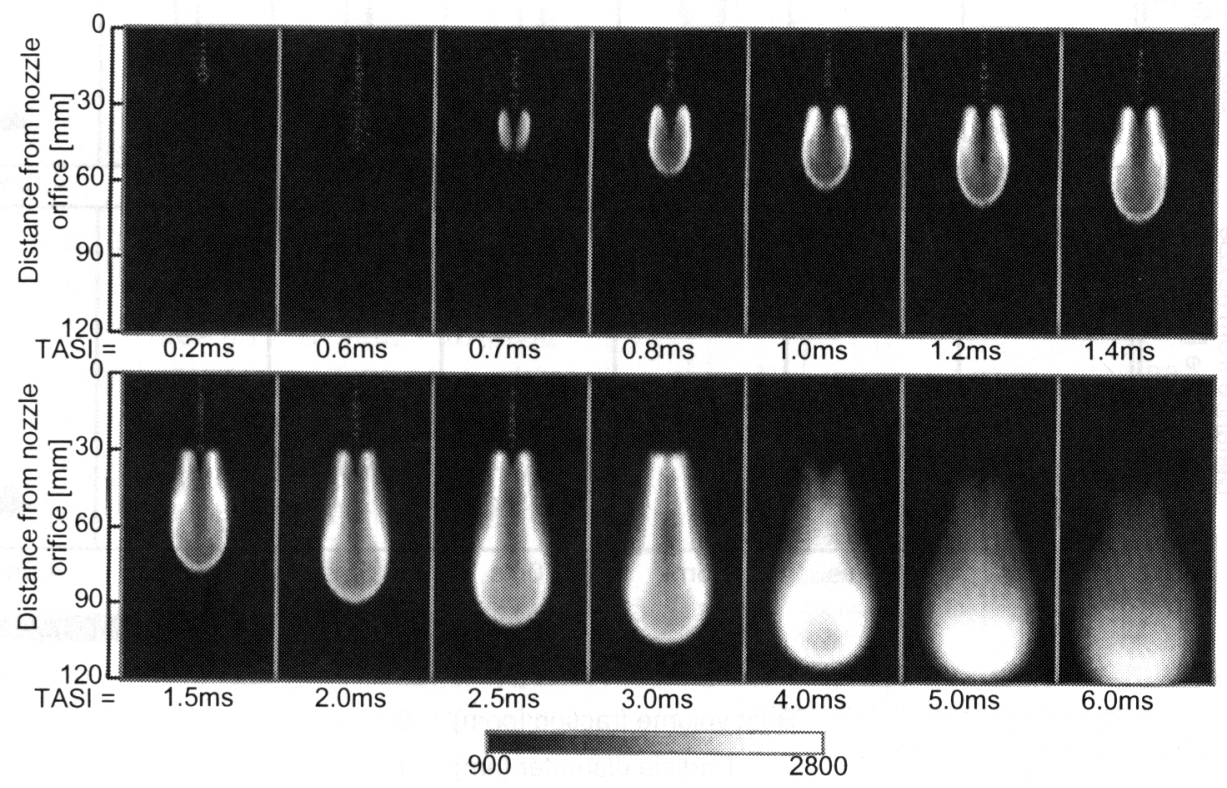

Fig. 4 Temporal change of distribution of flame temperature calculated by KIVA-3V coupled with detailed chemistry (fuel: n-heptane, $T_{a m b}=900[\mathrm{~K}], \rho_{a m b}=16.2\left[\mathrm{~kg} / \mathrm{m}^{3}\right], \Delta p_{i n}=70[\mathrm{MPa}], \Delta t_{i n}=2.65[\mathrm{~ms}]$ ) 
いる．噴射開始後 $0.7 \mathrm{~ms}$ 付近で噴孔出口から約 $40 \mathrm{~mm}$ の位置に明確な温度上昇がみられ，その後噴霧の発達 とともに，高温領域が拡大寸る．燃料噴射期間中は噴 孔出口から $40 \mathrm{~mm}$ 付近に噴射軸方向の温度勾配が急峻 な領域が存在し，ディーゼル噴霧然焼でみられる火炎

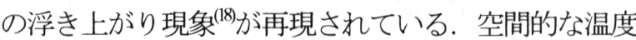
分布に着目すると，噴射終了後を除いて周用ガスとの 混合が活発な噴霧外縁で温度が高く，噴霧中心軸付近 で低い傾向を示している.

\section{3 すす粒子生成·成長過程}

図 5 (a) にす寸前駆体の代表として二環芳香族ナフ タレンの濃度, (b)にす寸体積濃度, (c)にす寸粒子径の 時間変化を示す。ナフタレンは明確なす寸生成が見ら れる時期に先駆けて噴霧火炎内部全域に高濃度で生成 され，その後，その生成領域の外縁側加す寸粒子 と変化していく様子が伺える．また，噴霧半径方向の 分布に着目寸ると，燃料噴射期間中は噴霧中心軸付近 に高濃度のナフタレンが分布し，それを包むように高 濃度のす寸が分布する傾向を示している。一方，噴霧 軸方向で比較すると, ナフタレン濃度は比較的上流側 で高く, 下流に向かうに従い寸寸粒子一と変化し，噴

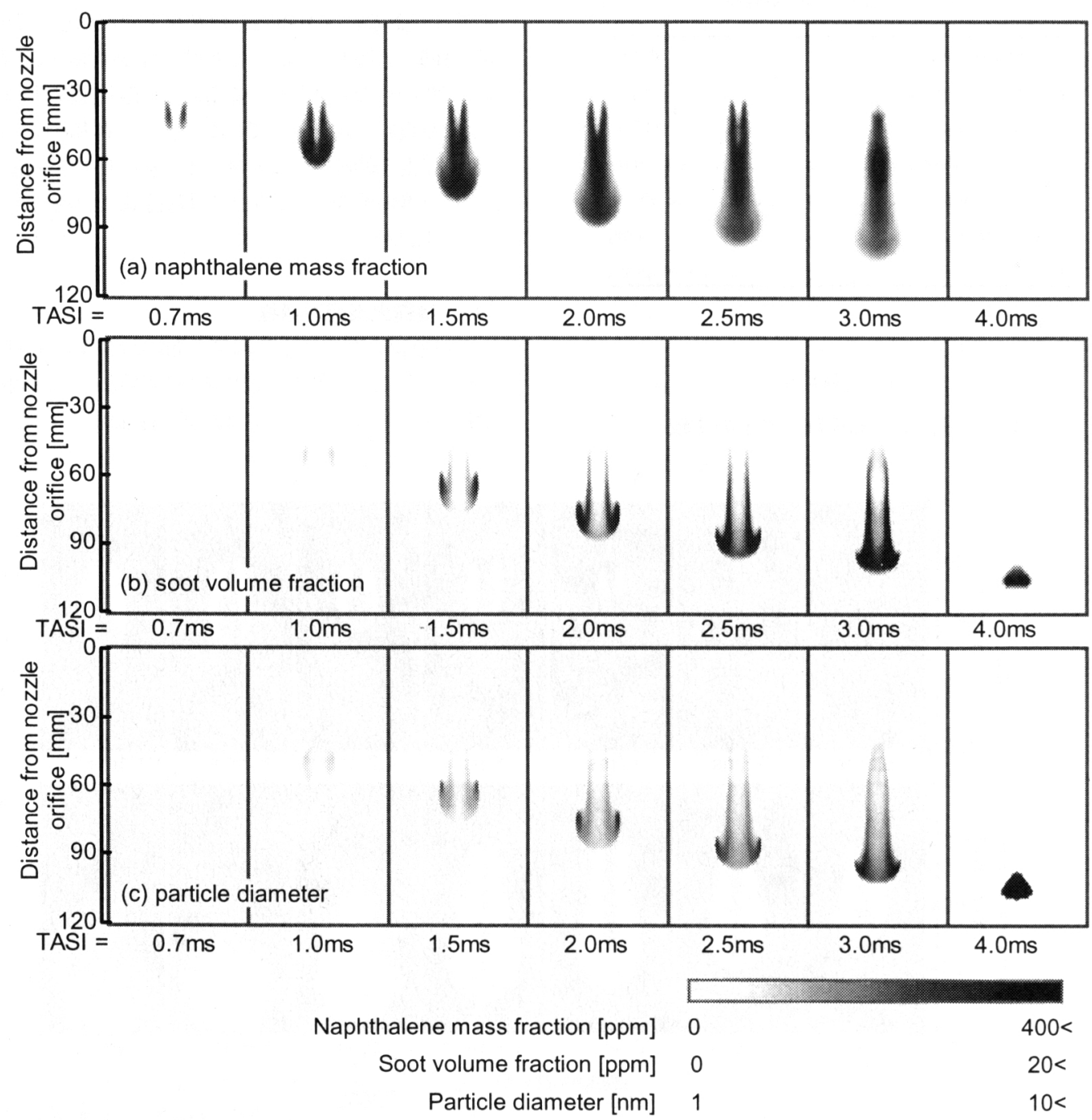

Fig. 5 Two-dimensional distribution of naphthalene mass fraction, soot volume fraction and particle diameter in diesel jet flame calculated by KIVA-3V coupled with detail soot model. (fuel: $\mathrm{n}$-heptane, $T_{a m b}=900[\mathrm{~K}], \rho_{a m b}=16.2\left[\mathrm{~kg} / \mathrm{m}^{3}\right], \Delta p_{i y}=70[\mathrm{MPa}], \Delta t_{i y}=2.65[\mathrm{~ms}]$ ) 
霧先端付近に高濃度のす寸が分布する様子が伺える. なお，三環，四環芳香族の濃度分布も定性的にナフタ レンの分布と一致する。これらの傾向は相澤らの PAH-LIF と LII の同時 2 次元計測により得られた結果 ${ }^{(2)}$ と定性的に良い一致を示している.

次に粒子径に着目すると，す寸生成開始直後は $5 \mathrm{~nm}$ 以下の微小粒子が殆どであり, 噴射開始からの時 間の経過に伴い, 噴霧の外縁から大粒子のす寸へと成 長する様子が伺える. また噴霧中心軸付近は小粒子径 のす寸で占められており，この領域では粒子の成長が 緩慢であることが示唆される. なおディ一ゼル噴霧火 炎内の寸寸粒子径の定量的計測法は確立されておらず, 粒子径の絶対值の妥当性を議論することは困難である. しかしながら定性的な粒子径の分布に関しては, これ までのレーザ計測により得られた結果 ${ }^{(1)(19)}$ と良い一致 を示しており，噴霧火炎内におけるす寸粒子の成長お よひ酸化過程を比較的よく再現できていると考えられ る.

図 6 に燃料噴射開始後 $2.5 \mathrm{~m}$ におおて, す寸粒子の 成長過程で重要な役割を担う核生成速度, アセチレン の付加反応による表面成長速度, $\mathrm{OH}$ ラジカルおよび 酸素分子によるす寸粒子の酸化反応速度の空間分布を 示す．核生成速度の高い領域はナフタレン濃度の高い 領域とほぼ一致しており, 主に噴霧中心軸付近に分布 している. 一方, アセチレン表面反応速度は核生成が 盛んな領域よりも噴霧外縁よりの領域で高い值を示し ている. 従って, 噴霧外縁です寸濃度が高く, 粒子径 が大となるのは, この領域でアセチレンによる表面反 応が活発であるためと結論付けられる.

す寸粒子の酸化は主に粒子表面における炭素原子 と酸化剤が反応することにより進行する. 本計算モデ ルでは酸化剤として火炎中での濃度が十分高い酸素分 子および $\mathrm{OH}$ ラジカルを考慮しているが， $\mathrm{OH}$ ラジカ ルの表面反応速度は酸素分子のものに比べ 100 倍程度 高く, すすの酸化反応は主に $\mathrm{OH}$ ラジカルによる表面 反応が支配的といえる. なお酸化反灾が活発な領域は アセチレン表面反応が高い值を示寸領域とほぼ一致し ており，噴霧の外縁側の比較的高温な領域に位置する.

\section{5. 結 論}

多次元流体解析コード KIVA3-V と反応解析コード CHEMKIN を連結し, ディーゼル噴霧火炎内部のすす 粒子生成過程を対象に詳細反応過程を考慮した化学反 応論的解析を行い. 以下に示寸知見を得た.
（1）本計算手法は，すす前躯体濃度，すす体積濃 度, およびすす粒子径の時空間分布に関して, これまでのレーザ計測により得られた下記(2) 〜(4)の項目を定性的に再現できる.

(2) 寸寸粒子前躯体である PAH は噴霧中心軸付近 で濃度が高く，それを包むように高濃度のす す粒子が分布する.

（3） PAH は噴霧上流側で濃度が高く，す寸粒子は その下流域で高濃度を示す.

（4）噴霧中心軸付近は小粒子径のすすが分布して おり，大粒子径のすすは噴霧外縁側に位置す

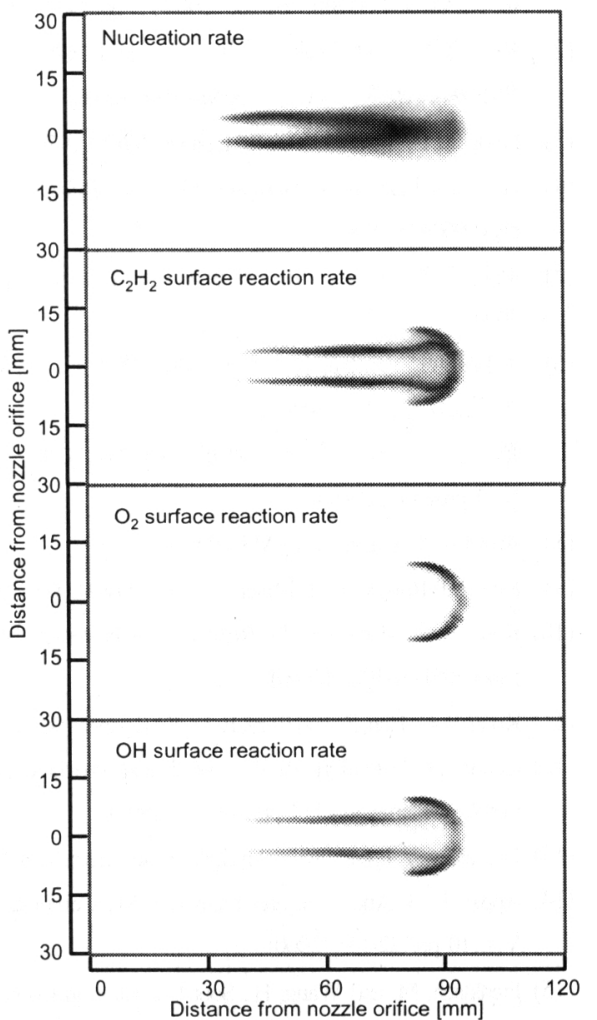

Nucleation [particle $/ \mathrm{cm}^{3} \mathrm{~s}$ ] 0 $7 \times 10^{18}<$ Surf $\mathrm{C}_{2} \mathrm{H}_{2}$ [carbon $/ \mathrm{cm}^{3} \mathrm{~s}$ ] 0 $3 \times 10^{21}<$ Surf $\mathrm{O}_{2}$ [carbon $/ \mathrm{cm}^{3} \mathrm{~s}$ ] 0 $6 \times 10^{19}<$ Surf $\mathrm{OH} \quad\left[\right.$ carbon $\left./ \mathrm{cm}^{3} \mathrm{~s}\right] \quad 0$ $5 \times 10^{21}<$

Fig. 6 Distribution of nucleation rate, $\mathrm{C}_{2} \mathrm{H}_{2}, \mathrm{O}_{2}$ and $\mathrm{OH}$ surface reaction rate in diesel jet flame calculated by KIVA-3V coupled with detailed soot model (fuel: $n$ heptane, $\quad T_{a m b}=900[\mathrm{~K}], \quad \rho_{a m b}=16.2[\mathrm{~kg} / \mathrm{m} 3]$, $\Delta p_{i n}=70[\mathrm{MPa}]$, TASI $=2.5[\mathrm{~ms}]$ 
る.

（5）噴霧内の粒子核生成速度の分布は PAH 濃度分 布と強い相関を持ち，噴霧中心軸付近で高い 值を示し，またアセチレンの表面反応による 粒子成長速度は核生成が活発な領域よりも噴 霧外縁側で高い值を示す.

（6）すす粒子の酸化反応は酸素分子よりも $\mathrm{OH}$ ラジ カルによる反応が支配的であり，噴霧外縁の 高温領域で活発である。

\section{参考文献}

（1）小酒英範，西垣隆弘，原田伸一，神本武征，日本機 械学会論文集(B 編)，61 巻，590 号，pp.28-33，1995

（2）相澤哲哉，小酒英範，松井幸雄，日本機械学会論文 集(B編)，69 巻，680 号，pp.981-987，2003

(3) Hiroyasu, H. and Kadota, T., SAE paper 760129, 1976

(4) Han, Z., Uhudogan, A., Hampson, G. H. and Reiz, R. D., SAE paper 960633,1996

(5) 高鳥芳樹, 秋浜一弘, 燃焼研究, 122 号, pp.21-31, 2000

（6）北村高明, 伊藤貴之, 千田二郎, 藤本元, 自動車技 術会論文集，Vol.34,No.1,pp.33-38

（7）草鹿仁，大聖泰弘，自動車技術会論文集，Vol.32， No.2,pp.43-48,(2001)

(8) Amsden, A. A., LA-13313-MS, (1997)

(9) Kee, R. J., Rupley, F. M., Miller, J. A., SAND 89-8009, (1989)

(10) Kong, S.-C., Marriott, C. D., Reit, R. D., Christensen, M., SAE paper 2001-01-1026, (2000)

(11) Kong, S.-C., Han, Z, and Reit, R. D., SAE paper 950278,(1995)

(12) Curran, H. J., Gaffuri, P., Pit, W. J. and Westbrook, C. K, Combust. Flame, Vol.114,pp.149-177,(1998)

(13) Golvichev, V.I., http://www.tdfchalmers.se/valeriMECH.html

(14) Apple, J., Bockhom, H. and Frenklach, M., Combust. Flame, Vol.110,pp.122-136,(2000)

(15) Frenklach, M. and Wang, H., Soot Formation in CombustionMechanism and Models, ed. Bockhom, H., Springer-Verlag, pp.165-192,(1994)

(16) Senda, J., Dan, T., Takagishi, S., Kanda, T., Fujimoto, H., Proceedings of ICLASS-97(Seoul), pp.149-156,(1997)

(17) Han, Z. and Reitz, R. D., Combust. Sci. and Tech, vol. 106, pp.267-295,(1995)

(18) Siebers, D. and Higgins, B., SAE paper 2001-01-0530, (2001)

(19) Dec. J. E., Espey, C., SAE paper 950456, (1995) 